Constant Venesoen, né en Belgique, vit au Canada depuis 1956. Ancien professeur à l'Université de Western Ontario, il est l'auteur d'ouvrages sur Racine, Corneille et Molière. Il est aussi l'auteur de deux recueils de poèmes: Catadioptres (1986) et Jeux de mots (1989). Une suite de sonnets, "Femmes de Racine," ont paru dans LittéRéalité en 1990.

\title{
***
}

\section{La Faim}

Les yeux écarquillés, leurs maigres mains tendues,

Le ventre ballonnant sur leur chair qui est nue, Les lèvres crevassées de plaies et de pustules, Les enfants de la faim sous ton oeil déambulent.

Ils ne comprennent pas ni pourquoi ni comment

La misère ou la mort tiennent lieu de tourment.

D'un regard éperdu ils tâtent leur peau grise, Victimes oubliées que le sort brutalise.

Le monde les nourrit, de pain ou de pitié, S'émeut le temps d'un flash, puis oublie leur contrée, Discute des anomalies démographiques, Et de ses sages remèdes prophylactiques.

Sournoise et sûre comme un ultime poison, Cette faim qui ronge le corps des moribonds Trébuche quelquefois dans sa démarche folle, Quand l'amour à sa rage se donne et s'immole.

Quand nos sens révoltés écartèlent le coeur, Quand la chair frémit et que le rire se meurt, Quand du gouffre de notre coupable conscience Un spectre émacié montre notre indifférence. 
Chevaliers du néant ou disciples des cieux, Peu importe au pauvre d'où sont venus tes dieux, L'amour du gueux est une vertu baptismale, Une manne d'espoir, une claire eau lustrale.

\section{La Solitude}

Je soliloque, en murmures et en soupirs, Divaguant au fond de ma mémoire fébrile, Et j'extirpe du creux de tous mes souvenirs La solitude obscure de l'âge imbécile.

Bercé dans le silence des flots maternels, Je m'étends, je m'ébats, rassuré je me couche, Je voudrais la tiédeur de l'amour éternel Que me promet la claire chanson de sa bouche.

Je vis recroquevillé, je songe à demain, A ce jour aveuglant, quand sa chair se déchire, A l'heure où naîtra ce qu'on appelle l'humain, Angoissé et perdu en mon pauvre délire.

Je m'accroche à ses flancs embrasés par le feu De ses folles passions dont je suis une braise, Je prie saint Virgile de m'accorder le voeu D'un seul mois de sursis pour que mon coeur s'apaise.

Douce retraite du ventre capitonné, Je ne crains pas la mort, seulement la naissance, Car il faudra, vivant, suivre ma destinée Parmi la foule, le bruit et l'intolérance.

La solitude n'est qu'un univers d'enfant, Une bulle ouatée où s'étire le bien-être, Un désert dans la nuit, un reflet du néant, Où vivre et rêver paisiblement s'enchevêtrent. 


\section{La Bêtise}

Bêtise culottée, cécité de l'ignare,

Comprenne qui voudra, le vulgaire s'y plie.

Compétence ennemie, haïe comme une tare,

Tu gênes son règne, tu menace sa vie.

Fière de son masque de déesse imbécile,

Elle traîne partout en putain déguisée.

Sa cour s'étend aux sots, aux naîfs, aux débiles,

Perclus d'ignorance, sourds à la vérité.

Elle a son bréviaire, répons et prières,

Recettes sans sel et formules avachies,

Ses meilleurs lieux communs se couvrent des oeillères

Qui font le bonheur des cervelles ramollies.

Elle s'enfle de ses connaissances obscures,

De son savoir banal, de mille erreurs criblé.

Son expérience n'est qu'une caricature

Qui reflète sa sottise et sa vanité.

De son sourire creux elle trompe tout le monde

Comme d'autres engendrent de tristes cocus,

Sa bouche régurgite une morne faconde

Que seuls avaleront les nigauds, les tordus.

Bêtise, sache-le, tu nous casses la tête, A tous tu donnes mauvaise réputation, Le bon sens a compris que tu es malhonnête, Et te dit, de grâce, un peu plus de discrétion. 